\title{
Creatiever werken door COVID-19
}

Het coronavirus betekende een totale ommezwaai in de huisartsenzorg. Alle aandacht ging uit naar het virus. Patiënten met 'gewone' aandoeningen konden alleen als het hoogstnoodzakelijk was een consult op de huisartsenpraktijk afspreken. Poh's moesten oplossingen bedenken voor de controles van patiënten met chronische aandoeningen. Zal dat consequenties hebben op de lange termijn?

Eind mei werden de resultaten bekend van een aantal onderzoeken. Het Nederlands Instituut voor Onderzoek van de Gezondheidzorg (Nivel) inventariseerde op verzoek van het ministerie van VWS en de Nederlands Zorgautoriteit (NZa) bij alle Nederlandse huisartsenpraktijken hoe de zorg was veranderd. In totaal gaven 1.443 huisartsenpraktijken (35\%) inzicht in de veranderingen die hadden plaatsgevonden in hun praktijk tijdens de COVID19-pandemie. Ook werd gevraagd in hoeverre de zorgmedewerkers verwachten dat deze veranderingen blijvend zullen zijn.

De NVvPO deed behoeftenonderzoek onder haar leden, waarbij ook gevraagd werd of ze verwachten dat de rol van poh's blijvend gaat veranderen. Zelf stelde ik diezelfde vraag via het poh-account op HAweb.

\section{Digitaal en telefonisch}

Om ondanks alles goede zorg te kunnen leveren, vereiste de COVID-19-crisis een creatieve aanpak. Controles van patiënten met chronische aandoeningen werden uitgesteld of vonden telefonisch plaats, per e-mail of internet. Huisartsenpraktijken hebben massaal het beeldbellen, teleconsultatie en beeldconsultatie ontdekt. In betere tijden zou dit een innovatieve aanpak heten. Houden we die aanpak erin, ook in tijden dat het virus minder (of wie weet: niet) toeslaat?

\section{Oversterfte niet alleen door COVID-19}

Er overleden in het eerste halfaar van 2020 meer mensen dan anders, en dat kwam niet alleen door COVID-19, was het vermoeden. In Europese landen begon de oversterfte vanaf half maart op te lopen.

Cardioloog Rudolf de Boer van UMC Groningen was een van de auteurs van een artikel over de'vergeten slachtoffers'. Dat artikel staat op medrxiv. org, een website voor onderzoek dat nog beoordeeld moet worden door vakgenoten. De onderzoekers verzamelden gegevens over de oversterfte in verscheidene Europese landen. Ook in Nederland overleden in het voorjaar meer mensen dan normaal in deze tijd. Bij vergelijking van de oversterfte met het aantal coronadoden, bleek er een gat te zijn van 51 procent. Met andere woorden: de oversterfte kwam lang niet alleen door het coronavirus. Welke doden betreft dit? Misschien wel mensen met meer klachten van hun chronische aandoening die zich niet bij de huisarts hebben gemeld omdat ze bang waren in een ziekenhuis met coronapatiënten terecht te komen. 


\section{'Er ligt een stuwmeer aan uitgestelde zorg'}

Een paar reacties op HAweb: 'Nu veel meer telefoon en digitaal werken. Toch heeft dat ook zijn voordelen. Daarom denk ik dat dit een grotere plaats gaat innemen dan voor de coronacrisis.' En: 'Beeldbellen zal door blijven gaan. Waarom ook niet? Wat betreft CVRM: de meeste mensen hebben een bloeddrukmeter thuis. Vanaf 1 juli hebben we OPEN. DM-patiënten kunnen zelf prikken en hun glucosewaardes doorgeven. Verwacht dat je de patiënten ook één of twee keer per jaar kunt zien in plaats van vier keer per jaar.'

Bellen en vormen van e-health, al dan niet met beeld, zullen dus blijven, is de verwachting. Dat blijkt ook uit het onderzoek van het Nivel: tijdens de COVID-19-pandemie is 64 procent van de praktijken voor het eerst gaan beeldbellen met patiënten.

Hiervan geeft 28 procent aan deze toepassing ook na de pandemie intensiever te blijven inzetten.
Ineens halen we een van de doelstellingen die de vorige minister van VWS jaren geleden al opstelde. In 2014 stelde minister Schippers het doel dat uiterlijk in 2019 driekwart van de chronisch zieken en kwetsbare ouderen zelfstandig metingen zou kunnen uitvoeren. Dat doel werd niet gehaald, want vorig jaar bleek uit een studie van het Nivel dat slechts vier op de tien mensen met een chronische aandoening zelf gezondheidswaarden meet.

\section{Geen oplossing voor alles}

Toch zijn er ook twijfels. Een van de poh's schrijft op HAweb: 'Maar bijvoorbeeld controles van astma/COPD (longfuncties) en voetonderzoek zullen op de praktijk moeten.' En een ander schrijft: 'Videobellen is (nog) niet echt mijn kopje thee. Van de week had ik een stoppen-met-rokengesprek. Ideaal zou je denken, maar voor echt contact is video toch te mager. Patiënt keek steeds weg en stiltes laten vallen, voelt (nog) ongemakkelijk tijdens zo'n videosessie.'

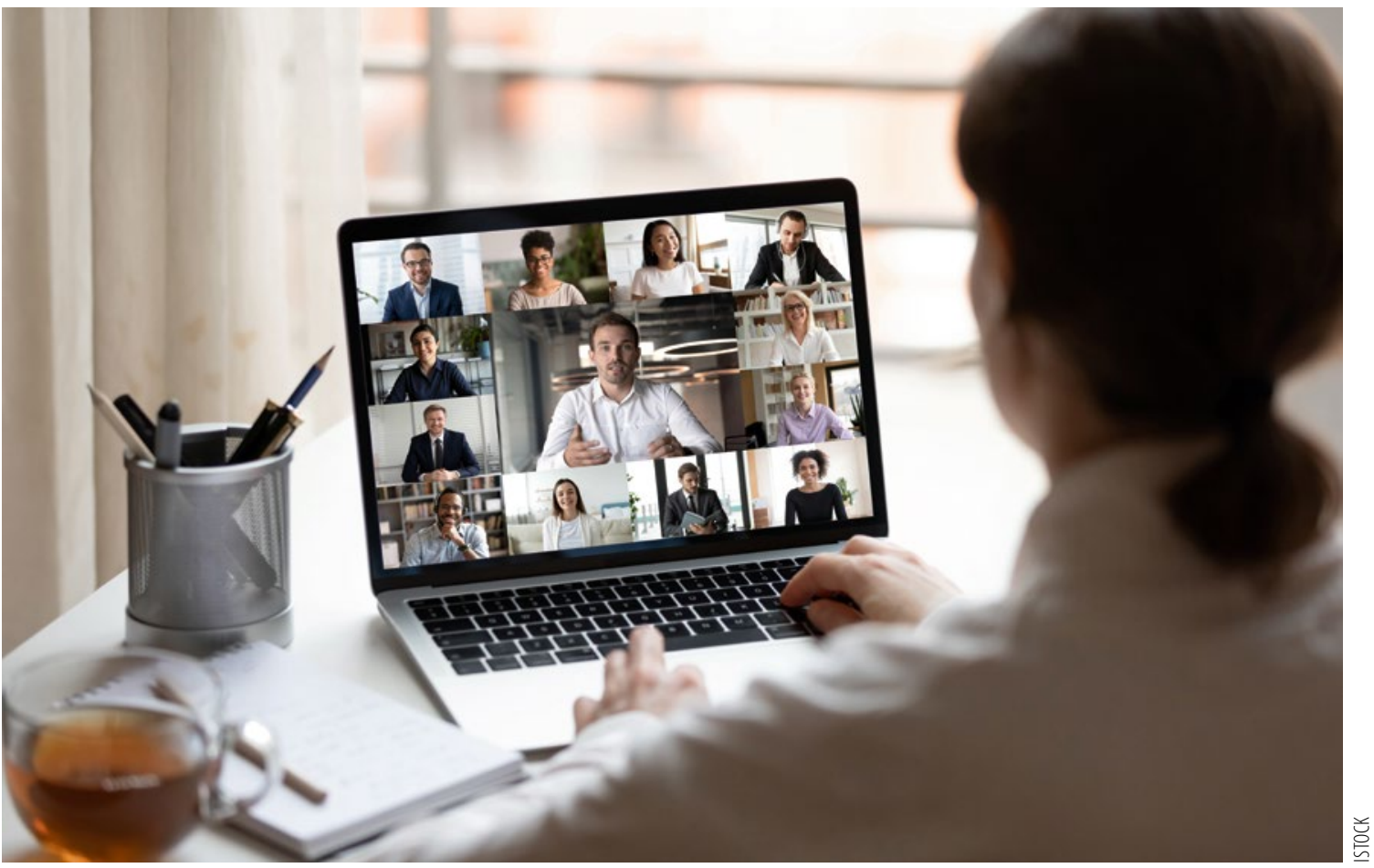


In de ouderenzorg lijkt contact per telefoon en via beeldschermen niet haalbaar en ook niet wenselijk. Visites en face-to-facecontact moeten blijven, volgens een poh-ouderen.

'Ik merk als poh-ouderen dat hoe langer deze tijd duurt van maatregelen rond ouderen, hoe meer crisissituaties er ontstaan. Door minder fysiek contact (=visites) mis je juist ook je eigen observaties die je tijdens de visite bespreekbaar maakt. Het monitoren en signaleren van achteruitgang of toename van kwetsbaarheid.'

\section{Zorg op maat}

Zorg op maat leveren wordt nog belangrijker als we besluiten tot teleconsultatie, is de strekking van de reacties van de poh's. Een van hen verwoordde het als volgt: 'Zorg op maat zal denk ik nog meer een rol gaan spelen. Ook vóór de coronatijd moesten we al kiezen om af en toe de protocollen te negeren. Dat is dan wel een bewuste keuze van mij en de huisarts, samen met de patiënt.' Voor de patiënten die zelfredzaam zijn en die de eigen regie kunnen voeren, is het allemaal niet zo moeilijk, schrijft ze, maar: 'Voor degene die dat niet kunnen, moeten we de zorg bieden zoals die was. Samen met de patiënt gaan we dus nu meer kiezen of we de patiënt fysiek moeten zien of dat het ook telefonisch of digitaal kan.' Zorg op maat is dus een vereiste, maar alsjeblieft met minder 'afvinken'! Voor het stroomlijnen van teleconsultatie komen ongetwijfeld nieuwe voorschriften en richtlijnen waar we ons aan te houden hebben, verwachten de poh's. Een citaat: 'Laten we bij het bieden van zorg op maat meteen eens echt kritisch kijken naar de "afvinkverplichting" en een betere manier zoeken om de kwaliteit van zorgverlening te toetsen. Daaruit voortkomend zie ik ook graag meer eigen verantwoordelijkheid voor de patiënten met betrekking tot het maken van en het verschijnen op afspraken.'

\section{Meer patiënten}

Zal COVID-19 het werk van de poh inhoudelijk veranderen? Dat weet op dit moment uiteraard niemand, maar een aantal poh's verwacht dat wel. 'Op longgebied zullen we er zeker een ziekte bij krijgen en als ik de berichten mag geloven eentje die voor de patiënten een chronisch verloop heeft', is een reactie van een van de poh's. Dat sluit aan bij de bezorgde berichtgeving van het Longfonds over het feit dat een deel van de coronapatiënten blijvende longschade aan het virus overhoudt. Vooral patiënten die op de intensive care moeten worden beademd, hebben risico op blijvende schade aan het longweefsel. Er is een nieuwe longziekte ontstaan, die vooralsnog de naam COVID Associated Lung Disease (CALD) draagt. De verwachting is dat ook de groep die hieraan lijdt (gedeeltelijk) voor begeleiding bij poh's zal komen.

De NVvPO stelde in haar onderzoek de vraag of poh/pvk's verwachten dat ze een andere rol zullen krijgen door de gevolgen van het coronavirus. Van de respondenten antwoordde 72 procent bevestigend. Uit de opmerkingen die ze bij het antwoord maakten, bleek dat ze verwachten (nog) meer preventief te werk te moeten gaan, zeker bij de patiënten die wat betreft het coronavirus een risicogroep blijken te vormen door hun overgewicht.

\section{Uitgestelde zorg}

Poh's verwachten het ook drukker te krijgen met patiënten voor wie noodzakelijke zorg steeds is uitgesteld of die zelf besloten niet meer naar controles te komen vanwege het risico op besmetting. Huisartsen zagen de laatste maanden tot 70 procent minder patiënten op hun spreekuur en ook bij bijvoorbeeld cardiologen bleven patiënten met hart- en vaatziekten massaal weg. Hun aandoening kan verergerd zijn in die tijd, waardoor ze misschien zelfs korter leven en met verminderde kwaliteit. Onderzoeksbureau Gupta deed daar onderzoek naar. Het uitstel van de normale zorg zal volgens dit bureau leiden tot een totaal verlies van 100- tot 400 duizend gezonde levensjaren. Het kan niet anders dan dat dit ook een verergering van chronische aandoeningen betekent, waardoor poh's het in de komende jaren mogelijk nog drukker gaan krijgen. Er ligt een stuwmeer aan uitgestelde zorg, zo groot dat het nog wel even kan duren voordat alle patienten weer terecht kunnen.' 